\title{
Physicochemical Properties of North African Donkey Milk
}

\author{
Mohamed Aroua ${ }^{1,3 *}$, Bayrem Jemmali², Samia Ben Said ${ }^{3}$, Hayet Ben Haj Kbaier ${ }^{3}$ and Mokhtar Mahouachi ${ }^{3}$ \\ ${ }_{1}^{1}$ Institut National Agronomique de Tunis, Université de Carthage, Tunisie \\ ${ }^{2} A D I P A R A$ Lab-Ecole Supérieure d'Agriculture de Mateur, Université de Carthage, Tunisie \\ ${ }^{3}$ Ecole Supérieure d'Agriculture du Kef, Université de Jendouba, Tunisie
}

Submission: March 23, 2019; Published: April 17, 2019

"Corresponding author: Mohamed Aroua, Institut National Agronomique de Tunis, Université de Carthage, Tunisie

\begin{abstract}
The present work was undertaken to study the physicochemical characteristics of North African donkey milk. Chemical composition of donkey milk was carried out for dry matter, fat, crude protein, $\mathrm{pH}$, lactose and ash using an automated milk analyzer. The results showed that the North African donkey milk composition was: dry matter $9.42 \%$, ash $0.35 \%$, fat $1.09 \%$, lactose $7.02 \%$ and protein $1.44 \%$. Further research on milk production, milk functionality, and valorization, market development, and genetic selection will help to better preserve and use of donkeys.
\end{abstract} Keywords: Donkey milk; North african; Physicochemical; Production

Abbreviations: TN: Total Nitrogen; NPN: Non-Protein Nitrogen; NCN: Non-Casein Nitrogen

\section{Introduction}

The donkey is an animal that first started to localize in northeastern Africa. It was tamed in Egypt around 4000-5000 BC and in the Middle East around $100 \mathrm{BC}[1,2]$. The donkey's milk was utilized as a breast milk substitute because for its comparative dietary synthesis unusually low casein content [3], and high substance of lysozyme $1 \mathrm{mg} / \mathrm{l}$ [4]. It is increasingly more used to sustain unfavorably susceptible children to dairy animals milk $[5,6]$. Lately, a few analysts demonstrated the impacts of donkey's milk on atherosclerosis aversion [7], they additionally shown that it has an antibacterial, antiviral and antitumor effect [3,8-11]. In the end, Donkey's milk is exceptionally utilized for corrective reasons.

In Tunisia, the donkey was utilized in homesteads for horticultural work. Donkey's milk wasn't valorized yet. National insights demonstrate a headcount of 123000 [12] unequally appropriated in a Tunisian area; actually, rugged, fringes and focus districts hold most of a donkey.

Barely any examinations concerning this topic were completed, for example, which is keen on the phenotypic portrayal of donkey breeds in Tunisia, [13] has considered the microbiological nature of Arabian donkey milk. Along these lines, it appears to be imperative to concentrate on this species that is by all accounts a commercial potential for Tunisian ranchers later on. For these reasons, this examination is keen on donkey milk piece of Tunisian donkey breed.

\section{Materials and Methods}

\section{Donkey milk sample}

The study was conducted among North African donkeys reared in the traditional breeding system in El Kef (Northwest of Tunisia) and Zaghouan (Northeast). This breed is considered very useful in a mountainous area for agricultural work. A total of 80 records were used to analyze the milk yield. Milk samples were immediately cooled and transported to the laboratory under refrigerated conditions $\left(4^{\circ} \mathrm{C}\right)$.

\section{Chemical composition of donkey milk}

Milk samples were analyzed for dry matter, fat, protein, ash, and lactose contents using an automated milk analyzer "Lactoscan MCC" calibrated for donkey milk. Nitrogen fractions of milk (total nitrogen (TN), non-protein nitrogen (NPN) and noncasein nitrogen (NCN)) were determined using Kjeldahl method according to the ISO 8968-1 (2014) in order to calculate casein concentrations $\mathrm{TC}=(\mathrm{TN}-\mathrm{NCN}) * 6.38$ and whey proteins $\mathrm{WP}=$ ((NCN- NPN)*6.38). 


\section{Results and Discussion}

Average daily milk yield and physicochemical composition of donkey milk have been presented in Table 1 . The average milk production of North African doneky's breed is $0.723 \pm 0.12 \mathrm{~kg}$. It is higher than that of the littoral-Dinaric donkey $(0.172 \mathrm{~kg})[14]$ and the Ragusana asses $(0.55 \mathrm{~kg}$ ) [15]. The distinction in milk creation is influenced by the genetic potential, milking number, both breed and the reproducing season [16].

Table 1: Daily milk yield and physicochemical characteristics of North African donkey milk.

\begin{tabular}{|c|c|}
\hline Composition (\%) & Donkey Milk \\
\hline Milk Yield (Kg/day) & $0.723 \pm 0.12$ \\
\hline Dry Matter & $9.42 \pm 0.59$ \\
\hline Ash & $0.35 \pm 0.09$ \\
\hline Protein & $1.44 \pm 0.12$ \\
\hline Fat & $1.09 \pm 0.22$ \\
\hline Lactose & $7.02 \pm 0.53$ \\
\hline Casein & $0.64 \pm 0.12$ \\
\hline NPN & $0.22 \pm 0.09$ \\
\hline Whey Protein & $0.59 \pm 0.19$ \\
\hline pH & $7.06 \pm 0.04$ \\
\hline
\end{tabular}

The dry matter $(9.42 \%)$ is higher than the results revealed by [13] for the Arabian donkey (8.62 \%). The total unrefined protein content $(1.44 \%)$ is as per the outcomes acquired by $[17,18]$. It is composed of $0.64 \%$ of casein, $0.59 \%$ whey protein and $0.22 \%$ of NPN. Donkey's milk three noteworthy whey protein are $\beta$-lactoglobulin $(\beta$-Lg), $\alpha$-lactalbumin $(\alpha$-La) and lysozyme which is a special additive, giving an extensive period of usability to crude donkey's milk [19]. Besides, it contains immunoglobulin (Igs), lactoferrin which has a critical antimicrobial bacterial activity by hydrolyzing of glycosidic obligations of mucopolysaccharides in bacterial cell walls [20] and lactoperoxidase which add to improving the regular additive activity of donkey milk.

The whey protein content is a crucial part in jenny milk for its properties in the skin maturing rebuilding process [21], in quieting bothering [22] and lessening the frequency of gastrointestinal diseases in new born children [23]. The observed standard milk fat substance is like the data detailed by [24] 1.15\% for Italian jackass and higher than element specified for by [14]. The solid substance is helpful for the treatment of some atopic dermatitis [25].

The regular lactose content $(7.02 \%)$ is as per their established by $[13,17]$. The high lactose content adds to the sweet taste of jenny milk, advances the intestinal retention of calcium and phosphorus and impacts the mineral collection in bone structure [26]. Donkey milk has a neutral pH (7.06), it is in accordance with their founded by $[13,17,18]$.

\section{Conclusion}

For its different healthful and functional characteristics, donkey's milk has been considered an exciting substitute for breast milk; it can be the best "pharma food" for people experiencing distinctive nourishment hypersensitivities, skin and bone issues. These days, for its multidisciplinary, utilize, for example, beauty care products, therapeutic and medical problems donkey milk turn out to be increasingly more looked for which makes the exploration of their creation likely outcomes sensible. Further, it is required to improve rearing practices to upgrade milk generation and potential impacts on milk quality.

\section{References}

1. Beja-Pereira A, England PR, Ferrand N, Jordan S, Bakhiet AO, et al. (2004) African origins of the domestic donkey. Science 304(5678): 1781.

2. Clutton-Brock J (1999) A natural history of domesticated mammals ( $2^{\text {nd }}$ edn). Cambridge University Press, London, UK.

3. Tidona F, Sekse C, Criscione A, Jacobsen M, Bordonaro S, et al. (2011) Antimicrobial effect of donkeys' milk digested in vitro with human gastrointestinal enzymes. International Dairy Journal 21(3): 158-165.

4. Vincenzetti S, Polidori P, Mariani P, Cammertoni N, Fantuz F, et al. (2008) Donkey's milk protein fractions characterization. Food Chemistry 106(2): 640-649.

5. Lauzier AC (2011) Pratiques d'allaitement à Port-Royal et aux Enfants-Assistés à la fin du XIXe siècle. Mémoire pour le diplôme d'Etat de sage-femme, Faculté de médecine de Paris, Ecole de Sage-femme de Baudelocque. p. 83.

6. Polidori P, Vincenzetti S (2013) Use of donkey milk in children with cow's milk protein allergy. Foods 2(2): 151-159.

7. Tafaro A, Magrone T, Jirillo F, Martemucci G, D'alessandro A, et al. (2007) Immunological properties of donkey's milk: its potential use in the prevention of atherosclerosis. Curr Pharm Des 13(36): 3711-3717.

8. Brumini D, Criscione A, Bordonaro S, Vegarud GE, Marletta D (2016) Whey proteins and their antimicrobial properties in donkey milk: a brief review. Dairy science \& technology 96(1): 1-14.

9. Šarić LĆ, Šarić BM, Kravić SZ, Plavšić DV, Milovanović IL, et al. (2014) Antibacterial activity of domestic Balkan donkey milk toward Listeria monocytogenes and Staphylococcus aureus. Food and Feed Research 41(1): 47-54.

10. Yvon S, Olier M, Leveque M, Jard G, Tormo H, et al. (2018) Donkey milk consumption exerts anti-inflammatory properties by normalizing antimicrobial peptides levels in Paneth's cells in a model of ileitis in mice. Eur J Nutr 57(1): 155-166.

11. Zhang XY, Zhao L, Jiang L, Dong ML, Ren FZ (2008) The antimicrobial activity of donkey milk and its microflora changes during storage. Food Control 19(12): 1191-1195.

12. ONAGRI (2018) Observatoire National de l'Agriculture. Observatoire National de l'Agriculture.

13. Charfi I, Rezouga F, Makhlouf A, Bornaz S (2018) The behaviour of Arabian donkey milk during acidification compared to bovine milk. International Journal of Dairy Technology 71(2): 439-445.

14. Ivanković A, Ramljak J, Štulina I, Antunac N, Bašić I, et al. (2009) Characteristics of the lactation, chemical composition and milk hygiene quality of the Littoral-Dinaric ass. Mljekarstvo/Dairy 59(2). 
15. Alabiso M, Giosuè C, Alicata M, Mazza F, Iannolino G (2009) The effects of different milking intervals and milking times per day in jennet milk production. Animal 3(4): 543-547.

16. Aspri M, Economou N, Papademas P (2017) Donkey milk: An overview on functionality, technology, and future prospects. Food reviews international 33: 316-333.

17. Aroua M, Jemmali B, Said S, Touati I, Mahouachi M (2018) Milk composition Comparison between donkey, goat and cow breeds. Journal of new sciences 9(5): 202-206.

18. Salimei E, Fantuz F (2012) Equid milk for human consumption. International Dairy Journal 24(2): 130-142.

19. Šarić LĆ, Šarić BM, Mandić AI, Torbica AM, Tomić JM, et al. (2012) Antibacterial properties of domestic Balkan donkeys' milk. International dairy journal 25(2): 142-146.

20. De Araujo AN, Giugliano LG (2001) Lactoferrin and free secretory component of human milk inhibit the adhesion of enteropathogenic Escherichia coli to HeLa cells. BMC Microbiol 1: 25
21. Nazzaro F, Orlando P, Fratianni F, Coppola R (2010) Isolation of components with antimicrobial property from the donkey milk: A preliminary study. Open Food Science Journal 4: 37-42.

22. Vincenzetti S, Amici A, Pucciarelli S, Vita A, Micozzi D, et al. (2012) A proteomic study on donkey milk. Biochem Anal Biochem 1: 109.

23. Businco L, Giampietro PG, Lucenti P, Lucaroni F, Pini C, et al. (2000) Allergenicity of mare's milk in children with cow's milk allergy. J Allergy Clin Immunol 105(5): 1031-1034.

24. Guo R, Sun D, Tan Z, Rong D, Li C (2006) Two recessive genes controlling thermophotoperiod-sensitive male sterility in wheat. Theor Appl Genet 112(7): 1271-1276.

25. Horrobin DF (2000) Essential fatty acid metabolism and its modification in atopic eczema. Am J Clin Nutr 71(1 Suppl): 367s-372s.

26. Monti G, Bertino E, Muratore MC, Coscia A, Cresi F, et al. (2007) Efficacy of donkey's milk in treating highly problematic cow's milk allergic children: an in vivo and in vitro study. Pediatr Allergy Immunol 18(3): 258-264.

\begin{tabular}{l} 
Your next submission with Juniper Publishers \\
will reach you the below assets \\
- Quality Editorial service \\
- Swift Peer Review \\
- Reprints availability \\
- E-prints Service \\
- Manuscript Podcast for convenient understanding \\
- Global attainment for your research \\
- Manuscript accessibility in different formats \\
( Pdf, E-pub, Full Text, Audio) \\
- Unceasing customer service \\
Track the below URL for one-step submission \\
https://juniperpublishers.com/online-submission.php \\
\hline
\end{tabular}

